УДК $338.242 ; 339.972$

\title{
ТРЕХКОМПОНЕНТНАЯ КОНЦЕПЦИЯ СОГЛАСОВАННОЙ ПРОМЫШЛЕННОЙ ПОЛИТИКИ В ЕАЭС
}

\author{
В.Л. ГУРСКИЙ \\ канд. экон. наук, доцент, заведующий кафедрой экономики \\ БИП-Институт правоведения, г. Минск
}

\begin{abstract}
Аннотация
В статье проводится анализ факторов препятствуюших развитию взаимной торговли, промышленному сотрудничеству и кооперации в ЕАЭС. Сделан вывод, что сложившиеся условия уже нельзя характеризовать как кризис, это скорее новые условия хозяйствования, требуюшие согласования действий и объединения усилий в области промышленной политики стран-членов. Предложена трехкомпонентная модель формирования согласованной промышленной политики стран ЕАЭС, включающая: согласование условий торговли и промышленной кооперачии в ЕАЭС; согласование национальных промышленных политик стран-членов; проведение совместной наднациональной промышленной политики ЕАЭС.

Ключевые слова: промышленная политика, международное промышленное сотрудничество.
\end{abstract}

\section{Abstract}

This paper analyzes the factors hindering the development of bilateral trade, industrial cooperation and cooperation in the EAEU. It was concluded that current conditions can no longer be characterized as a crisis, but rather new economic conditions, requiring concerted action and joint efforts in the field of industrial policy of the member countries. The article suggests a threecomponent model of a concerted industrial policy in EAEU countries, including the harmonization of trade and industrial cooperation in the EAEU; coordination of national industrial policies of member countries; enforcement of joint supranational industrial policy of EAEU.

Key words: industrial policy, International Industrial Cooperation.

\section{ВВЕДЕНИЕ}

Углубляющийся технологический и технический отрыв промышленности развитых стран, определяющий снижение конкурентоспособности и потерю рыночных позиций отечественных производителей на мировом рынке, политика новой индустриализации в 
развитых странах сопровождающаяся активным ограничением доступа к новейшим и стратегически важным технологиям для остальных стран, усиление глобальной конкуренции на мировых рынках и в ЕАЭС, появление новых центров мирового экономического развития (Индия, Китай), падение цен на сырьевые ресурсы и введение санкций против России стали причинами серьезных внешнеэкономических шоков для всех стран ЕАЭС. В Республике Беларусь падение экспорта наблюдается третий год подряд, а в 2015 году экспорт упал на 26,1\% (по организациям промышленности на 29,4\%). Падение промышленного производства в 2015 году в сопоставимых ценах составило 6,6\%, (ВВП упал на 3,9\%) [1]. Индексы объемов промышленного производства 2015 к 2014 году, в пересчете на доллары США еще хуже: Армения 90,3\%, Беларусь 68,2\%, Казахстан 63,8\%, Кыргызстан 84,8\%, Россия 66,6\% [2]. Все это требует существенных изменений в проводимой интеграционной и промышленной политике стран ЕАЭС, требует совместных, согласованных действий, что и определяет высокую актуальность рассматриваемого вопроса.

В Беларуси вопросы развития промышленного комплекса и промышленной политики изучали С. Миксюк [3], М.В. Мясникович [4], С.С. Сидорский [5], А.Н. Сенько [6], И.Л. Телеш [7], А.М. Сасим [8], В.Ф. Байнев [9], Е.Н. Филиппенко [10], С.Ю. Солодовников [11]. Вопросы связанные с промышленной политикой в процессе интеграционного взаимодействия рассматривали Н.А. Бровко [12], С.Ю. Глазьев [13], М.Ю. Ильина [14], А.М.Выжитович, П.А. Ершов [15]. Проблемой оценки уровня согласованности экономических интересов субъектов региональной промышленной политики занимались Ю.А. Фридман, Г.Н. Речко, О.А. Бияков, Ю.Ш. Блам [16]. Достаточно подробный анализ теоретико-методологических основ промышленной политики и зарубежного опыта ее осуществления провел авторский коллектив во главе с К.Н. Андриановым [17].

Многочисленные публикации по вопросам интеграции стран ЕАЭС в основном касаются возможностей и перспектив, которые открываются для промышленных комплексов стран участниц при условии проведения согласованной экономической политики в ЕАЭС, не углубляясь, однако, в проблематику практического осуществления процесса согласования. Департаментом промышленной политики Евразийской экономической комиссии во главе с Сидорским С.С. разработаны «Основные направления промышленного сотрудничества в рамках ЕАЭС» [18], где сделана попытка проанализировать существующее положение в области промышленной политики и развития промышленности стран ЕАЭС на данный момент, а также обобщить основные направления и инструменты промышленного сотрудничества в рамках ЕАЭС предложенные на 
межправительственном уровне, однако авторы работы ограничились в основном их перечислением, почти не касаясь проблематики их практической реализации.

Цель данной работы провести анализ факторов препятствующих процессу развития промышленных комплексов стран ЕАЭС, разработать модель формирования согласованной промышленной политики стран ЕАЭС на основе сочетания тактических и стратегических компонентов совместной деятельности в данной области.

\section{РЕЗУЛЬТАТЫ И ИХ ОБСУЖДЕНИЕ}

Анализ основных тенденций в мировой экономике, а также внутренних факторов сдерживающих развитие промышленности в ЕАЭС показывает, что на современном этапе проявился ряд объективных препятствий, барьеров и противоречий как внешних, так и внутренних. Сложившиеся условия уже нельзя характеризовать как кризис, это скорее новые условия хозяйствования, требующие адекватной реакции в области промышленной политики страны.

Таблица 1 - Внешние и внутренние условия развития промышленности стран ЕАЭС на современном этапе

\begin{tabular}{|l|l|}
\hline \multicolumn{1}{|c|}{ Внешние условия } & \multicolumn{1}{|c|}{ Внутренние условия } \\
\hline $\begin{array}{l}\text { Ослабление национальных валют стран } \\
\text { ЕАЭС и связанное с этим повышение } \\
\text { ценовой конкурентоспособности на рынках } \\
\text { третьих стран. }\end{array}$ & $\begin{array}{l}\text { Ослабление национальных валют стран ЕАЭС } \\
\text { и связанное с этим снижение экспортных цен } \\
\text { и экспортной выручки) внутри ЕАЭС }\end{array}$ \\
\hline $\begin{array}{l}\text { Падение цен на нефть и нефтепродукты, } \\
\text { калийные удобрения и связанное с этим } \\
\text { сокращение валютных поступлений для всех } \\
\text { стран ЕАЭС. }\end{array}$ & $\begin{array}{l}\text { Сокращение объемов взаимной торговли } \\
\text { стран ЕАЭС между собой и одновременное } \\
\text { сокрание импорта из третьих стран. }\end{array}$ \\
\hline $\begin{array}{l}\text { Сокращение спроса на отечественную } \\
\text { продукцию обрабатывающей } \\
\text { промышленности за рубежом }\end{array}$ & $\begin{array}{l}\text { Сокращение внутреннего спроса в станах } \\
\text { ЕАЭС связанное с экономическим спадом }\end{array}$ \\
\hline $\begin{array}{l}\text { Усиление качественной конкуренции на } \\
\text { внешних рынках, трудности в наращивании } \\
\text { несырьевого экспорта в третьи страны }\end{array}$ & $\begin{array}{l}\text { Усиливающаяся ценовая и неценовая } \\
\text { конкуренция между производителями } \\
\text { промышленной продукции внутри ЕАЭС } \\
\text { между собой }\end{array}$ \\
\hline $\begin{array}{l}\text { Нестабильность мировой экономики } \\
\text { (повторяющиеся мировые экономические } \\
\text { кризисы) }\end{array}$ & $\begin{array}{l}\text { Высокая зависимость темпов развития } \\
\text { экономик стран ЕАЭС от состояния мировой } \\
\text { экономики и цен на сырьевые товары. }\end{array}$ \\
\hline
\end{tabular}


Окончание таблицы 1

\begin{tabular}{|c|c|}
\hline Внешние условия & Внутренние условия \\
\hline $\begin{array}{l}\text { Усиление экономического противостояния } \\
\text { важнейших торговых партнеров (санкции } \\
\text { против России, ответное эмбарго со стороны } \\
\text { России, противостояние Украины и России, } \\
\text { запрет на трансфер технологий со стороны } \\
\text { развитых стран и др.). }\end{array}$ & $\begin{array}{l}\text { Сокращение внутрисоюзных и транзитных } \\
\text { перевозок и как следствие значительное } \\
\text { падение объемов выручки компаний } \\
\text { перевозчиков и поступлений таможенных и } \\
\text { транспортных сборов в бюджет }\end{array}$ \\
\hline $\begin{array}{l}\text { Усиление роли ТНК и ФПГ в мировой } \\
\text { экономики и торговле }\end{array}$ & $\begin{array}{l}\text { Снятие барьеров в рамках Союза формирует } \\
\text { условия для более широких возможностей } \\
\text { производителя, одновременно усиливая } \\
\text { конкуренцию }\end{array}$ \\
\hline $\begin{array}{l}\text { Политика новой индустриализации в } \\
\text { развитых странах }\end{array}$ & $\begin{array}{l}\text { Широкомасштабная модернизация } \\
\text { промышленности в ЕАЭС (особенно России и } \\
\text { Беларуси) }\end{array}$ \\
\hline $\begin{array}{l}\text { Нарастающая сложность производственных } \\
\text { процессов, усложнение самой продукции, } \\
\text { процессов ее конструирования, } \\
\text { проектирования, управления производством }\end{array}$ & $\begin{array}{l}\text { Несовершенная технологической структуры } \\
\text { промышленного комплекса, }\end{array}$ \\
\hline $\begin{array}{l}\text { Ограничения на продажу } \\
\text { высокотехнологичной продукции и } \\
\text { технологий со стороны развитых стран }\end{array}$ & $\begin{array}{l}\text { Отставание во внедрении современных систем } \\
\text { управления процессами производства, } \\
\text { применении модульного принципа } \\
\text { проектирования, использовании быстро } \\
\text { переналаживаемых технологических линий }\end{array}$ \\
\hline
\end{tabular}

Негативное воздействие всего комплекса внешних и внутренних факторов во многом объясняет, почему в Беларуси и остальных странах ЕАЭС усилия правительств и проводимая промышленная политика пока не оказали существенного стабилизирующего эффекта на развитие промышленности. Решение всего комплекса обозначенных проблем для стран ЕАЭС невозможно в рамках чисто национальной промышленной политики, слишком высокий уровень открытости экономик. Очевидно, что изменение всего комплекса внешних и внутренних условий развития промышленности стран ЕАЭС требует мобилизации промышленнопроизводственного, научного и финансового потенциала всех странучастниц на основе согласованной промышленной политики.

Таким образом, основными факторами определяющими невозможность развития промышленности стран ЕАЭС в рамках только национальной промышленной политики и абсолютную необходимость проведения согласованной промышленной политики ЕАЭС в целом являются: 
- углубляющийся технологический и технический отрыв промышленности развитых стран, определяющий снижение конкурентоспособности и потерю рыночных позиций на мировом рынке;

- невозможность преодоления «технологического разрыва» в обозримой перспективе, в силу недостаточности собственных финансовых ресурсов и ограниченного доступа к заемным ресурсам;

- активное противодействие получению новейших и стратегически важных технологий со стороны развитых стран;

- усиление глобальной конкуренции на мировых рынках;

- использование третьими странами нерыночных методов в конкурентной борьбе (санкции, эмбарго и пр.);

- сокращение спроса на отечественную промышленную продукцию на мировых рынках.

Промышленная политика - это система принципов, инструментов и целей государственной координации экономического процесса в промышленности, посредством разработки долгосрочной экономической стратегии развития национального промышленного комплекса [19]. Исходя из общей теории управления, согласованность (координация) предполагает синхронизацию действий объектов и субъектов управления во времени и пространстве путем установления рациональных связей (коммуникаций) и обмена информацией между ними, с целью наиболее эффективного и оперативного достижения поставленных целей. Согласованность действий требует в первую очередь единства целей (их соответствие интересам каждого из участников), устранение противоречий между субъектами согласования, синхронизацию усилий и постоянный обмен информацией. В основном, осознание необходимости мобилизации промышленного и научного потенциала государств-членов ЕАЭС на уровне глав государств и правительств произошло, все участники интеграционного процесса понимают, что необходимы согласованные действия, однако механизм осуществления данного процесса пока отсутствует.

Цель промышленного сотрудничества в рамках ЕАЭС определена как: «реализация потенциала эффективного и взаимовыгодного взаимодействия государств обеспечения ускорения и устойчивости промышленного развития, повышения конкурентоспособности и инновационной активности промышленности государств» [20]. Предполагается что заданная цель будет достигнута путем развития кооперационного сотрудничества, импортозамещения промышленных товаров из третьих стран на общем рынке ЕАЭС, увеличения локализации производства, наращивание экспорта продукции обрабатывающей промышленности, ускорение технологического развития промышленных комплексов, устранения барьеров на пути движения промышленных 
товаров на общем рынке ЕАЭС [18]. Однако, все вышеперечисленные направления являются тактическими. Даже полное и успешное решение данных задач не позволит промышленности ЕАЭС достичь решающих, стратегических преимуществ в мировой экономике.

Согласованная промышленная политика ЕАЭС, на наш взгляд, должна строиться из трех ключевых компонентов:

- согласование условий торговли и промышленной кооперации в рамках ЕАЭС;

- согласование национальных промышленных политик стран ЕАЭС;

- проведение совместной наднациональной промышленной политики стран ЕАЭС.

Важно четко обозначить, ключевые элементы для каждого компонента. Как пишет Солодовников С.Ю., «самые необходимые составляющие промышленной политики любой формы и модификации, четко сформулированы цели, объекты и субъекты, а также инструменты и средства ее осуществления» [11].

Таблица 2 - Ключевые элементы трех компонентной концепции формирования согласованной промышленной политики ЕАЭС

\begin{tabular}{|c|c|c|c|}
\hline & $\begin{array}{c}1 \text { уровень } \\
\text { согласования } \\
\text { Согласование условий } \\
\text { движения товаров, } \\
\text { факторов производства и } \\
\text { знаний в рамках ЕАЭС }\end{array}$ & $\begin{array}{c}2 \text { уровень } \\
\text { согласования } \\
\text { Согласование } \\
\text { национальных } \\
\text { промышленных политик } \\
\text { и развитие } \\
\text { промышленной } \\
\text { кооперации стран ЕАЭС }\end{array}$ & $\begin{array}{c}3 \text { уровень } \\
\text { согласования } \\
\text { Проведение } \\
\text { совместной } \\
\text { наднациональной } \\
\text { промышленной } \\
\text { политики стран } \\
\text { ЕАЭС }\end{array}$ \\
\hline 1 & 2 & 3 & 4 \\
\hline $\begin{array}{l}\text { Предмет } \\
\text { согласования }\end{array}$ & $\begin{array}{l}\text { Система } \\
\text { межправительственных } \\
\text { договоров и соглашений } \\
\text { по либерализации и } \\
\text { унификации условий } \\
\text { движения товаров, } \\
\text { факторов производства и } \\
\text { знаний в рамках ЕАЭС, } \\
\text { проведение единой } \\
\text { таможенной политики в } \\
\text { отношении третьих стран. }\end{array}$ & $\begin{array}{l}\text { Инструменты } \\
\text { государственной } \\
\text { промышленной } \\
\text { политики, в т.ч. меры } \\
\text { государственной } \\
\text { поддержки, условия } \\
\text { защиты внутреннего } \\
\text { рынка, степень } \\
\text { локализации совместных } \\
\text { и иностранных } \\
\text { производств на } \\
\text { территории стран ЕАЭС, } \\
\text { преференции, льготы и } \\
\text { особые условия } \\
\text { налогообложения и др. }\end{array}$ & $\begin{array}{l}\text { Конкретные } \\
\text { мегапроекты } \\
\text { промышленного } \\
\text { инноваци-онного и } \\
\text { инвестиционного } \\
\text { сотрудничества } \\
\text { глобального } \\
\text { характера. Проекты } \\
\text { по формированию } \\
\text { совместных ТНК и } \\
\text { ФПГ, совместные } \\
\text { действия на } \\
\text { международной } \\
\text { арене. Программа } \\
\text { импорто-замещения } \\
\text { в рамках ЕАЭС. } \\
\text { Программа развития } \\
\text { и размещения } \\
\text { производи-тельных } \\
\text { сил ЕАЭС. }\end{array}$ \\
\hline
\end{tabular}


Окончание таблицы 2

\begin{tabular}{|c|c|c|c|}
\hline 1 & 2 & 3 & 4 \\
\hline $\begin{array}{l}\text { Субъект } \\
\text { согласования }\end{array}$ & $\begin{array}{l}\text { Президенты и } \\
\text { правительства стран- } \\
\text { членов, наднациональные } \\
\text { структуры ЕАЭС }\end{array}$ & $\begin{array}{l}\text { Все субъекты } \\
\text { промышленной политики } \\
{[19]}\end{array}$ & $\begin{array}{l}\text { Правительства стран, } \\
\text { наднациональные } \\
\text { структуры ЕАЭС, } \\
\text { крупные } \\
\text { хозяйствующие } \\
\text { субъекты }\end{array}$ \\
\hline $\begin{array}{l}\text { Объект } \\
\text { согласования }\end{array}$ & $\begin{array}{l}\text { Условия движения } \\
\text { товаров, факторов } \\
\text { производства и знаний в } \\
\text { рамках ЕАЭС. }\end{array}$ & $\begin{array}{l}\text { Национальные } \\
\text { промышленные политики, } \\
\text { Экономические интересы } \\
\text { субъектов национальных } \\
\text { промышленных политик } \\
\text { стран ЕАЭС. }\end{array}$ & $\begin{array}{l}\text { Долгосрочная } \\
\text { совместная } \\
\text { экономическая } \\
\text { стратегия развития } \\
\text { промышленного } \\
\text { комплекса ЕАЭС как } \\
\text { единой системы, } \\
\text { оказывающая } \\
\text { существенное } \\
\text { влияние на } \\
\text { геэкономическую } \\
\text { ситуацию в мировой } \\
\text { экономике, и } \\
\text { способная задать } \\
\text { долгосрочные тренды } \\
\text { в экономическом } \\
\text { развитии всего } \\
\text { Евразийского } \\
\text { континента. }\end{array}$ \\
\hline $\begin{array}{l}\text { Методы } \\
\text { согласования }\end{array}$ & $\begin{array}{l}\text { Переговоры глав } \\
\text { государств, } \\
\text { правительственных } \\
\text { комиссий, деятельность } \\
\text { наднациональных } \\
\text { структур ЕАЭС. }\end{array}$ & $\begin{array}{l}\text { Деятельность посольств и } \\
\text { торговых } \\
\text { представительств, } \\
\text { периодическое проведение } \\
\text { конференций и форумов, } \\
\text { создание } \\
\text { постояннодействующих } \\
\text { консультационных } \\
\text { межправительственных } \\
\text { центров и комиссий, } \\
\text { переговоры на уровне } \\
\text { отдельных предприятий, } \\
\text { межрегиональные } \\
\text { контакты местных органов } \\
\text { власти, контакты } \\
\text { соответствующих } \\
\text { министерств и ведомств. }\end{array}$ & $\begin{array}{l}\text { Совместное } \\
\text { стратегическое } \\
\text { планирование. }\end{array}$ \\
\hline $\begin{array}{l}\text { Цель } \\
\text { согласования }\end{array}$ & $\begin{array}{l}\text { Формирование условий } \\
\text { для быстрого и } \\
\text { эффективного трансфера } \\
\text { товаров, факторов } \\
\text { производства и знаний. }\end{array}$ & $\begin{array}{l}\text { Формирование единой } \\
\text { экономической системы в } \\
\text { промышленности путем } \\
\text { постепенного } \\
\text { качественного и } \\
\text { количественного усиления } \\
\text { взаимосвязей между } \\
\text { экономическими } \\
\text { субъектами. }\end{array}$ & $\begin{array}{l}\text { Завоевание } \\
\text { стратегических } \\
\text { конкурентных } \\
\text { преимуществ на } \\
\text { мировом рынке, } \\
\text { доминирование на } \\
\text { евразийском } \\
\text { экономическом } \\
\text { пространстве. } \\
\end{array}$ \\
\hline
\end{tabular}


По первому направлению, т.е. в области согласования условий движения товаров, факторов производства и знаний в рамках ЕАЭС сделано достаточно много. Регулярные встречи глав России и Беларусь, а также стран ЕАЭС, большое число подписанных межправительственных договоров и соглашений, многочисленные публикации по вопросам возможностей и перспектив от проведения согласованной экономической политики в ЕАЭС формируют основу для активного развития промышленного сотрудничества. Проводимая Департаментом промышленной политики ЕЭК в настоящее время работа направлена в основном на устранение барьеров препятствующих функционированию внутреннего рынка Евразийского экономического союза, а также изъятий и ограничений в отношении движения товаров, услуг, капитала и рабочей силы. Очевидно, что такая работа необходима, и является базисом для любых интеграционных процессов в международной экономике. Без подписания соответствующих договоров и соглашений речь шла бы не о формировании экономического союза и согласованной промышленной политики, a о простых торгово-экономических отношениях между странами. Вместе с тем, уже сейчас наблюдается явное несоответствие количества подписанных межправительственных соглашений («интеграции сверху»), и сокращающейся активности экономического взаимодействия субъектов хозяйствования («интеграции снизу»). Объективной причиной данного явления, на наш взгляд, является наличие собственных, национальных интересов у каждой страны и региона, что приводит к противоречию интересов субъектов хозяйствования. Интеграционная практика показывает, что общие для всех стран ЕАЭС интересы пока не сформированы [21]. В этой связи можно утверждать, что устранение барьеров и ограничений является необходимым, но недостаточным условием развития интеграции в ЕАЭС.

Анализируя динамику интеграционных процессов по второму направлению, т.е. промышленной кооперации и согласованию промышленных политик стран-членов, необходимо отметить, что сотрудничающие стороны активно ищут производственные проекты, позволяющие им максимально кооперироваться и «уходить» от простой купли-продажи. Наиболее крупные проекты производственной кооперации сложились между компаниями России и Беларуси. В области автомобилестроения традиционными стали связки: «МАЗ», «БелАЗ» -, «ГАЗ», «КамАЗ», «Силовые машины»; Минский моторный завод Тутаевский моторный завод; «Гомсельмаш», МТЗ, - «Ростсельмаш», «ЧТЗ-Уралтрак». Имеются проекты технологической кооперации России с Казахстаном в области техобслуживания и промышленной сборки вертолетов: «Вертолеты России» - «Казахстан Инжиниринг»; локомотивосборочный завод в Астане с учатием «Трансмашхолдинга» 
(Россия); производство вагонов на базе Алмаатинского вагоноремонтного завода. Примером кооперации между Беларусью и Казахстаном являются отношения между Петропавловским заводом тяжелого машиностроения и Минским заводом колесных тягачей. Кроме того, в Казахстане организовано 12 сборочных производств белорусской техники (ПО «БелАЗ», РУП «МТЗ», ПО «Гомсельмаш», ОАО «Минский моторный завод», ОАО «Минский автомобильный завод», РУП «Завод «Могилевлифтмаш», ОАО «Бобруйскагромаш» и ОАО «Белкард») [22]. Важным этапом научно-технического сотрудничества является принятое 13 апреля 2016 года Положение о формировании и функционировании евразийских технологических платформ [23] которые предполагается реализовать через участие Беларуси и Казахстана и других стран ЕАЭС в Российских технологических платформах, которые в свою очередь создавались по образу и подобию Европейских Технологических платформ.

Как видим, примеры сотрудничества несомненно есть, однако аналогичные примеры промышленного сотрудничества есть и с другими странами (например с Китаем). Очевидно, что ЕАЭС как глобальный интеграционный проект имеет гораздо больший потенциал и сотрудничества на существующем уровне явно не достаточно (иначе товарооборот между странами ЕАЭС не упал бы в 2015 году более чем на 25\% [24]). Заявленные основные направления промышленного сотрудничества такие как: Евразийские технологические платформы, Межгосударственные программы и проекты в инновационной сфере, Евразийские инновационные промышленные кластеры развиваются пока крайне медленно, а по вопросам согласования промышленных политик стран-членов ведется только предварительная, аналитическая работа анализа и сопоставления национальных программ развития промышленности. В реальности отсутствуют даже теоретикометодологические подходы к вопросу согласования. По данному направлению нами разработан алгоритм и предложена методика согласования интересов субъектов промышленных политик стран ЕАЭС, изложенные в ранее опубликованных нами работах [25].

Интеграционное объединение ЕАЭС само по себе является мегапроектом современности, однако пока это больше политический мегапроект, имеющий крайне слабое отражение в экономике стран участниц. Кроме того, по мере спада взаимной экономической активности и наращивания взаимовыгодного сотрудничества с третьими странами (например с Китаем), появляются некоторые сомнения в целесообразности, а главное в перспективности данного интеграционного образования. В этой связи, реализация третьего направления предложенной нами модели является совершенно необходимым условием 
его существования и развития. Масштабность самого понятия согласованной промышленной политики стран ЕАЭС, как и самого проекта ЕАЭС требует адекватных, масштабных задач. Очевидно, что задачи догоняющего типа априори закрепляют экономику ЕАЭС в положении аутсайдера (догоняющего). Для завоевания стратегических конкурентных преимуществ, необходимы задачи, меняющие саму архитектуру современной мировой экономики.

Третье направление предложенной нами модели предполагает проведение совместной наднациональной промышленной политики стран ЕАЭС, и в качестве основного механизма его реализации предлагается использовать стратегию реализации совместных глобальных мегапроектов (стратегических инициатив). Под глобальностью проекта понимается его способность существенно повлиять на геоэкономическую ситуацию в мировой экономике, а также задать долгосрочные тенденции в экономическом развитии всего Евразийского континента.

На национальном уровне подобных проектов реализуется, в настоящий момент, достаточно много, особенно в России: Программа комплексного перевооружения в России, Космическая программа России (ввод космодрома «Восточный» - её первый этап), Программа Развития авиационной промышленности, Мегапроекты «Урал полярный - Урал промышленный», «Ямал», освоение шельфа Баренцева моря, БАМ-2, Северный морской путь, и др. В Беларуси это строительство атомной электростанции, строительство второй кольцевой дороги в Минске. Многие из проектов реализуется совместно с Китаем, например Сила Сибири в России, Великий камень в Беларуси, освоение крупнейшего месторождения нефти Кашаган в Казахстане. Однако, совместных мегапроектов трех, а тем более пяти стран ЕАЭС пока не наблюдается.

Все вышеперечисленные проекты носят национальный характер, как по стратегическому замыслу, так и по ожидаемому эффекту, и не совсем подходят для консолидации промышленных комплексов стран ЕАЭС и агрегирования их в единую производственно-экономическую систему.

Проект должен, во-первых, быть востребован экономиками всех стран-участниц (что обеспечит их заинтересованность), а во-вторых должен обеспечить максимальную нагрузку на промышленный потенциал всех стран-участниц (что обеспечит их развитие и максимальный мультипликативный эффект).

В данном контексте принципиальным является даже не сам объект, т.е. определенный мегапроект, а конкретная точка приложения усилий всех стран ЕАЭС - процесс объединяющий усилия по развитию национальных промышленных комплексов, и направляющий их в едином направлении. Основные исходные требования к выбору мегапроекта можно сформулировать следующим образом: 
1. Возможность поэтапного осуществления, освоения и ввода в действие.

2. Максимальный геоэкономический эффект (проект должен объединить экономики стран ЕАЭС в единую производственноэкономическую систему и создать основу для ее расширения).

3. Максимальный мультипликативный эффект (проект должен стимулировать формирование длинных цепочек стоимости).

4. Повышение качества жизни граждан.

5. Максимальное использование собственного промышленнопроизводственного потенциала.

6. Стимулирование формирования высокотехнологичных производств.

7. Стимулировать развитие территорий не только в ЕАЭС но и у стран соседей.

8. Иметь возможность расширения и перспективы развития.

Интересующий нас мегапроект может быть связан с космическими технологиями (совместная космическая станция, полет на Марс). В его реализации сможет участвовать достаточно узкий круг промышленных предприятий в основном из России и Беларуси, однако, как отмечает С.Ю. Солодовников: «Учитывая косвенные эффекты, обусловленные трансферам технологий, продуктов и услуг, полученных в результате космической деятельности, в смежные и сопутствующие отрасли экономики, общий экономический эффект космической деятельности возможно оценить на уровне вклада в валовой внутренний продукт» [26]. Международный опыт показывает, что создание одного рабочего места в авиастроении формирует, от 50 до 100 рабочих мест в смежных отраслях.

Удачным, на наш взгляд, является вариант озвученный В.И. Матвиенко в докладе интеграционного клуба при председателе Совета Федерации Федерального Собрания Российской Федерации за 2015 год: «... о создании трансевразийского пояса развития, который может связать современной инфраструктурой Европу и Азию от Атлантического до Тихого океана, в несколько раз увеличить объемы и скорость пассажиропотоков, товарообмена, обмена информацией между ними. Реализация такого мегапроекта дала бы мощные стимулы строительной отрасли, IT-индустрии, энергетическому комплексу» [22]. Подобные проекты, предложенные Китаем это Железная дорога ПекинМосква через Алматы, Великий шелковый путь («Один пояс - один путь»). В мае 2015 года главы России и Китая подписали Совместное заявление Российской Федерации и Китайской Народной Республики о сотрудничестве по сопряжению строительства Евразийского экономического союза и Экономического пояса Шелкового пути. Беларусь 
и Казахстан также подключились к обсуждению данного вопроса и внесли свои предложения относительно маршрута строительства. Однако, идея сопряжения ЕАЭС и Экономического пояса Шелкового пути упирается в проблемы логистики, низкого уровня инфраструктуры на территории предполагаемого строительства и определенного недоверия друг другу. Кроме того, Китай совсем не спешит с реальным воплощением проекта. На наш взгляд, странам ЕАЭС необходим свой инфраструктурный проект. Например, создание трансевразийского транспортно-информационного коридора: одного с запада на восток, из Европы через Минск, Москву, Астану, Бишкек в Китай, второго с севера на юг, из Европы, через Минск, Москву, Тбилиси, Ереван, в Иран и Турцию. Предлагаемый коридор должен включать (как минимум) скоростную железную дорогу грузового и пассажирского назначения, линии высокоскоростной передачи информации большой пропускной способности (оптоволоконные или лучше), высоковольтные линии электропередач. Строительство таких транспортных коридоров позволит, во-первых, существенно повысить конкурентные преимущества и инвестиционную привлекательность всего региона, существенно повысить мобильность товаров, трудовых и прочих ресурсов, повысить качество жизни граждан, проживающих в регионе, вовлечь максимальное количество промышленных предприятий стран ЕАЭС, как традиционных, как и высокотехнологичных отраслей, обеспечив спрос на их продукцию и услуги на длительное время. Важным аспектом является то, что положительный эффект от реализации данного проекта возникает практически сразу (при строительстве даже небольшого отрезка пути) и возрастает по мере продолжения строительства. Обязательным условием реализации проекта является производство всего оборудования, транспортных средств и подвижного состава на территории ЕАЭС.

Как уже отмечалось ранее согласованная промышленная политика не заменяет и не отменяет национальных промышленных политик, так и совместная политика стратегических инициатив не должна заменять и отменять национальных проектов в промышленности. Совместная наднациональная промышленная политика стран ЕАЭС должна быть направлена вовне. Принципиальная схема сочетания трех направлений формирования согласованной промышленной политики стран ЕАЭС представлена на рисунке. 


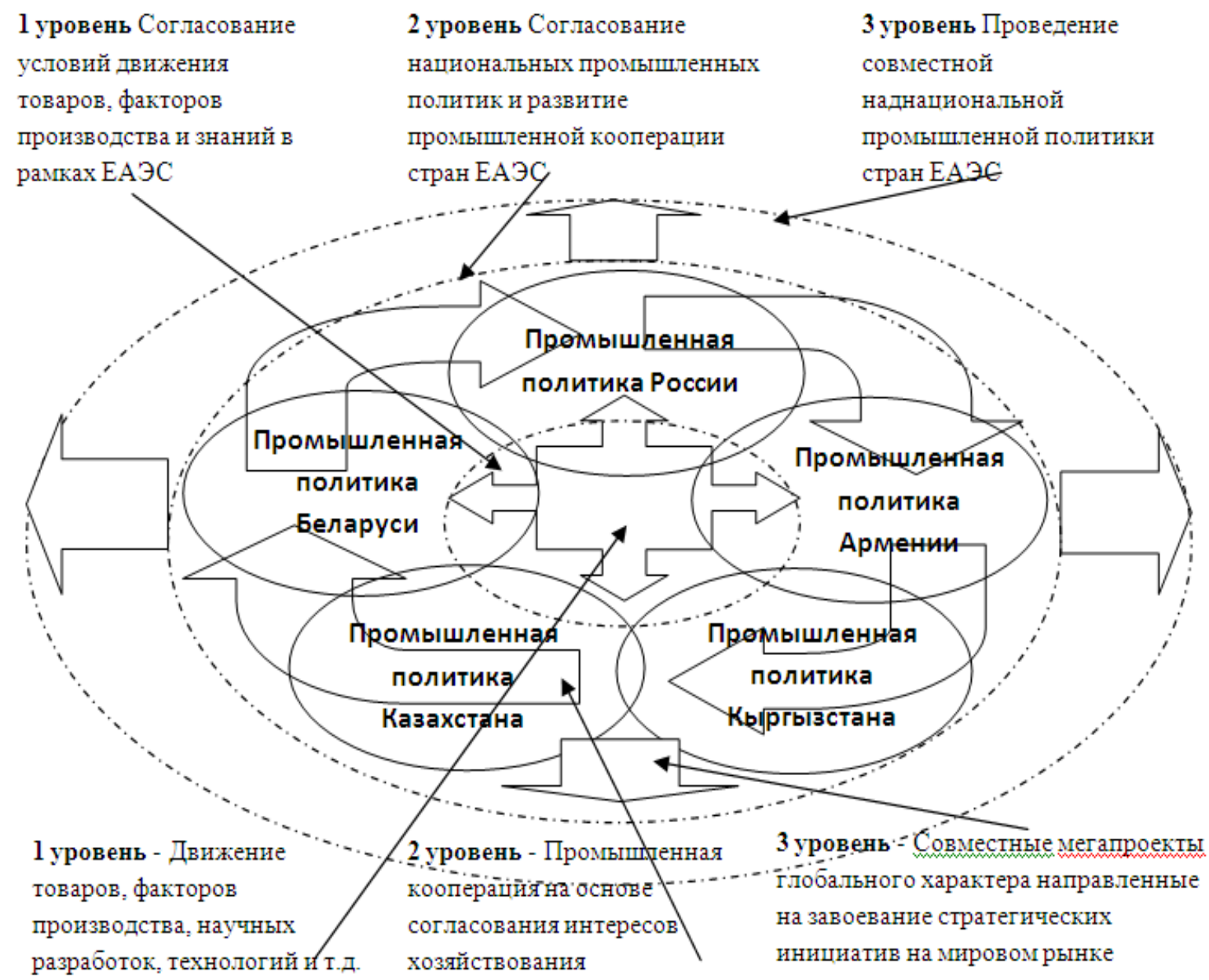

Принципиальная схема сочетания трех компонентов формирования согласованной промышленной политики стран ЕАЭС

Реализация предложенной концепции позволит преодолеть выявленные ранее факторы-ограничители развития промышленного комплекса ЕАЭС:

- сокращение спроса на отечественную промышленную продукцию на мировых рынках за счет активизации внутреннего спроса и мультипликативного эффекта при реализации совместных стратегических мегапроектов, совместной политики импортозамещения в рамках ЕАЭС;

- углубляющийся технический отрыв и противодействие получению новейших и стратегически важных технологий со стороны развитых стран за счет вовлечения заинтересованных стран и международных корпораций в реализуемые стратегические мегапроекты на условиях размещения новых производств на территории ЕАЭС, и переноса современных технологий, разработки собственных новейших технологий востребованных при реализации совместных мегапроектов; 
- усиление глобальной конкуренции на мировых рынках, снижение конкурентоспособности отечественных промышленных предприятий и потерю ими рыночных позиций на мировом рынке за счет политики импортозамещения в рамках ЕАЭС, изменения транспортных и информационных потоков, изменения позиции ЕАЭС в мировой экономике (уход от роли вечно догоняющего аутсайдера к роли задающего новые направления развития мировой экономики лидера);

- дефицит собственных финансовых ресурсов и ограниченный доступ к заемным ресурсам за счет объединения усилий 5 стран ЕАЭС, ресурсов Евразийского банка развития и привлечения инвесторов заинтересованных в реализации совместных мегапроектов;

- использование третьими странами нерыночных методов в конкурентной борьбе (санкции, эмбарго и пр.) за счет повышения заинтересованности международных корпораций и субъектов хозяйствования из третьих стран участвовать в реализации глобальных проектов, в инвестировании и других экономических отношениях с субъектами хозяйствования ЕАЭС (выстраивания отношений на уровне предприятий, минуя уровень государств).

\section{ВЫВОДЫ}

Подводя итог можно констатировать, что на современном этапе проявился ряд объективных препятствий, барьеров и противоречий сдерживающих развитие промышленности в ЕАЭС как внешних, так и внутренних. Сложившиеся условия уже нельзя характеризовать как кризис, это скорее новые условия хозяйствования, требующие адекватной реакции в области промышленной политики страны. Объективные факторы определяющие развитие промышленности всех стран ЕАЭС, такие как усиление глобальной конкуренции усугубляющаяся технологическими изменениями в промышленности и политикой новой индустриализации в развитых странах, появление новых центров мирового экономического развития (Индия, Китай), усиление конкуренции в самом ЕАЭС предопределяют необходимость мобилизации промышленного и научного потенциала государств-членов ЕАЭС, однако механизм осуществления данного процесса пока не проработан.

Нами предложено строить согласованную промышленную политику ЕАЭС на основе 3 ключевых компонентов: согласование условий торговли и промышленной кооперации в рамках ЕАЭС направленное на формирование условий для быстрого и эффективного трансфера товаров, факторов производства и знаний; согласование национальных промышленных политик стран ЕАЭС направленное на формирование единой экономической системы в промышленности путем постепенного 
качественного и количественного усиления взаимосвязей между экономическими субъектами; проведение совместной наднациональной промышленной политики стран ЕАЭС направленное на завоевание стратегических конкурентных преимуществ на мировом рынке, доминирование на евразийском экономическом пространстве. По каждому из обозначенных направлений уже имеется определенный задел, однако все осуществляемые в настоящее время мероприятия в данной области носят тактический характер, направлены на поддержание собственных предприятий стран-членов и не могут обеспечить стратегических конкурентных преимуществ как для национальных экономик по отдельности, так и для ЕАЭС в целом. Реализация предложенной концепции во многом позволит преодолеть выявленные ранее факторыограничители развития промышленного комплекса ЕАЭС.

\section{ЛИТЕРАТУРА}

1. Промышленность Республики Беларусь. Статистический сборник, 2016 [Электронный ресурс] / Национальный статистический комитет Республики Беларусь. - Минск, 2016. - Режим доступа: http://www.belstat.gov.by/ofitsialnaya-statistika / publications / izdania / public_ compilation/index_5412/. - Дата доступа: 16.08.2016.

2. Государства - члены Евразийского экономического союза в цифрах: статистический ежегодник [Электронный ресурс] / Евразийская экономическая комиссия. - Москва, 2015. - Режим доступа: http://www. eurasiancommission.org/ru/act/integr_i_akroec/dep_stat/econstat/Documents/ Stat_Yearbook_2015.pdf. - Дата доступа: 20.08.2016.

3. Миксюк, С.Ф. Концептуальные и методические подходы к среднесрочному прогнозированию развития промышленного комплекса Республики Беларусь / С.Ф. Миксюк, И.Л. Телеш, // Белорусский экономический журнал. - 2008. - № 1. - С. 36-45

4. Мясникович, М.В. Государственное регулирование инновационной деятельности: Уч. пос. / М.В. Мясникович, Н.Б. Антонова, Л.Н. Нехорошева. - Минск: Академия управления при Президенте Республики Беларусь, 2005. - 235 с.

5. Сидорский, С.С. Промышленное сотрудничество в ЕАЭС мощный фактор экономического развития [Электронный ресурс] / Республика. - Минск, 2015. - Режим доступа: http://respublika.sb. by/obshchestvo - 27/article/promyshlennoe-sotrudnichestvo-v-eaes-moshchnyyfaktor-ekonomicheskogo-razvitiya.html. - Дата доступа: 20.08.2016. 
6. Сенько, А. Н. Обеспечение экономической безопасности промышленного комплекса Республики Беларусь на стадии его роста: дис. д-ра эконом. наук: 08.00.05 / А. Н. Сенько. - Минск, 2008. - 245 л.

7. Телеш, И. Л. Совершенствование прогнозирования важнейших показателей развития промышленного комплекса Республики Беларусь: Дис. .канд. эконом. наук: 08.00.05 / И. Л. Телеш. - Минск, 2010. - 112 л.

8. Сасим, А. М. Промышленность Беларуси в XX столетии: учеб. пособие / А. М. Сасим. Минск: Экоперспектива, 2001.

9. Байнев, В. Ф. Факторы деиндустриализации и девальвация национальной валюты как важнейший из них / В. Ф. Байнев // Белорус. экон. журн. 2009. № 3. С. 14-24.

10. Филиппенко, Е. Н. Промышленная политика в транзитивной экономике / Е. Филиппенко // Журнал меж-дународного права и международных отношений. - 2010. - №2. - С. 22-26.

11. Солодовников, С.Ю. Понятие промышленной политики / М.С. Белявская, С.Ю. Солодовников // Устойчивое развитие экономики: состояние, проблемы, перспективы. Сборник трудов IX Международной научно-практической конференции. - Полесский государственный университет. - Пинск, 2015. - С. 11-12.

12. Бровко Н. А. Развитие экономических интеграционных процессов на современном этапе: дис. ... д-ра экон. наук: 08.00.01 / Н. А. Бровко. - Бишкек, 2011. - 330 с.

13. Глазьев, С.Ю. Доклад о целях проблемах и мерах государственной политики развития и развития и интеграции Москва, 29 Января 2013 [Электронный ресурс] / База документов. - Москва, 2013. Режим доступа: http://reftrend.ru/642462.html. - Дата доступа: 20.08.2016.

14. Ильина, М.Ю. Единое инновационное пространство как фактор реиндустриализации экономик государств - членов ЕАЭС [Электронный pecypc] / Сайт webeconomy.ru. - Режим доступа: http://www.webeconomy.ru/ index.php?page $=$ cat\&newsid $=3231 \&$ type=news. - Дата доступа: 20.08.2016.

15. Выжитович, А.М. Ершов П.А. Евразийская интеграция против импортозамещения: противоречия и возможности. [Текст] / А.М. Выжитович, П.А. Ершов. // Россия и евразийский мир: прошлое, настоящее, будущее : материалы междунар. науч.-практ. конф., г. Новосибирск, 15 мая 2015 г. / науч. ред. С. В. Козлов - Новосибирск : Изд-во СибАГС, 2015. - 362 с.

16. Фридман, Ю.А. Оценка уровня согласованности экономических интересов субъектов региональной промышленной политики / Ю.А. Фридман, Г.Н. Речко, О.А. Бияков, Ю.Ш. Блам / Регион: экономика и социология, 2008, № 3, с. 78-96. 
17. Промышленная политика в условиях новой индустриализации Андрианов К.Н. [и др.]; под ред. Толкачева С.А. - М.: МАКС Пресс, 2015. - 252 c.

18. Основные направления промышленного сотрудничества в рамках ЕАЭС / Евразийская экономическая комиссия [Электронный peсурс] / Евразийская экономическая комиссия. - Москва, 2016. Режим доступа: http://www.eurasiancommission.org/ru/act/prom_i_agroprom/ SiteAssets/брошюра\%20pyc\%200K\%20NEW.pdf. - Дата доступа 16.08.2016

19. Гурский, В.Л. Механизм действия факторов обусловливающих формирование и эволюцию промышленной политики в Республике Беларусь / В.Л. Гурский // Научные труды Академии управления при Президенте Республики Беларусь. - Минск: Акад. упр. при Президенте Респ. Беларусь. - Вып. 17. Экономика. Право. Идеология. - 2015. C. 109-123.

20. Об Основных направлениях промышленного сотрудничества в рамках Евразийского экономического союза Решение Евразийского Межправительственного Совета 8 сентября 2015 г. № 9 г. Гродно // Нац. правовой Интернет-портал Респ. Беларусь [Электронный ресурс] / Нац. центр правовой информ. Респ. Беларусь. - Минск, 2015. - Режим доступа: http://www.pravo.by/main.aspx?guid=3871\&p0= f91500234. - Дата доступа: 20.08.2016..

21. Гурский, В.Л. Объективные предпосылки несоответствия формальной и реальной составляющей процесса развития промышленного сотрудничества в рамках ЕАЭС / В.Л. Гурский // Развитие экономики политики социума: состояние, проблемы, перспективы: Научный журнал ISSN 2409-7799/ Санкт-Петербургский государственный экономический университет; гл. ред. А.Л.Пастухов. - Санкт-Петербург, 2016. - №5. C.44-59.

22. Научно-техническое сотрудничество как фактор евразийской экономической интеграции. Ежегодный доклад интеграционного клуба при председателе Совета Федерации Федерального Собрания Российской Федерации за 2015 год [Электронный ресурс] / Издание Совета Федерации. - Москва, 2016. - Режим доступа:http:/www.council.gov.ru/ media/files/ rAMxTGk0OVCzWQHTXaq4AwGba6Iplopl.pdf. - Дата доступа: 16.08.2016.

23. Об утверждении Положения о формировании и функционировании евразийских технологических платформ [Электронный ресурс] / Решение Евразийского межправительственного совета 13 апреля 2016 г. № 2.- Москва, 2016. - Режим доступа: http://test.pravo.by/ main.aspx?guid=3871 \&p0=F91600069. - Дата доступа: 16.08.2016. 
24. Об итогах взаимной торговли товарами Евразийского экономического союза Январь - декабрь 2015 года [Электронный ресурс] / Евразийская экономическая комиссия. - Москва, 2016. - Режим доступа: http://www.eurasiancommission.org/ru/act/integr_i_makroec/dep_stat/tradestat/ analytics/Documents/Analytics_I_201512.pdf. - Дата доступа: 20.08.2016.

25. Гурский, В.Л. Моделирование процесса согласования промышленной политики стран ЕАЭС / В.Л. Гурский // Сацыяльнаэканамічныя і прававыя даследаванні. - Минск, 2016. - № 2. - С. 121-134.

26. Солодовников, С.Ю. Проблемы и перспективы перехода Республики Беларусь к новому технологическому укладу: сквозь призму экономики космоса / С.Ю. Солодовников, А. А. Чурсин, Ю.В. Мелешко // Бизнес в законе. Экономико-юридический журнал. - 2015. - № 5. C. 241-246.

Статья поступила в редакцию 03 сентябряя 2016 года. 